\title{
Estimasi Aliran Panasbumi Menggunakan Data Geomagnetik Di Daerah Panasbumi Pulu
}

\author{
(Estimation of Geothermal Flow Using Geomagnetic Data in the \\ Geothermal Area of Pulu)
}

\author{
Fathana Rasyid*), Rustan Efendi, Sandra \\ Program Studi Fisika Jurusan Fisika FMIPA, Universitas Tadulako, Palu, Indonesia
}

\begin{abstract}
A research on estimation of geothermal flow using geomagnetic data in the geothermal area of Pulu. This study aims to determine subsurface heat flow in Geothermal Areas Pulu consisting of depth on (Zt), the depth of the center ( $\mathrm{Zo})$, the depth of basal $(\mathrm{Zb})$. Stages of research using spectral analysis techniques. Temperature gradient and heat flow is obtained by inserting the basalt depth value generated by using Equation Fourier Law. The results obtained showed the average value of the temperature gradient that is $0,21255{ }^{\circ} \mathrm{C}$ and the average value of the heat flow is $0.32298 \mathrm{mWm}^{-2}$.
\end{abstract}

flow

Key words: Magnetic Anomaly, Spectrum Analysis, temperature gradient, heat

\section{ABSTRAK}

Telah dilakukan penelitian estimasi aliran panasbumi menggunakan Data Geomagnetik di Daerah Panasbumi Pulu. Penelitian ini bertujuan untuk menentukan aliran panas bawah permukaan di Daerah Panasbumi Pulu yang terdiri dari kedalaman atas (Zt), kedalaman tengah $(\mathrm{Zo})$, kedalaman basal $(\mathrm{Zb})$. Tahapan penelitian menggunakan teknik analisis spektrum. Gradien temperatur dan aliran panas didapatkan dengan memasukkan nilai kedalaman basal yang dihasilkan dengan menggunakan Persamaan Hukum Fourier. Hasil yang di peroleh menunjukkan nilai rata-rata gradien temperatur yaitu $0,21255^{\circ} \mathrm{C}$ dan nilai rata-rata aliran panas yaitu $0,32298 \mathrm{mWm}^{-2}$.

Kata kunci : Anomali magnetik, Analisis Spektrum, Gradien Temperatur, Aliran panas

\section{LATAR BELAKANG}

Energi panasbumi adalah energi panas yang tersimpan dalam batuan di bawah permukaan bumi dan fluida yang terkandung di dalamnya. Pemanfaatan energi panasbumi untuk sektor non-listrik (direct use) telah berlangsung di Italia sekitar 70 tahun. Saat ini energi panasbumi 
telah dimanfaatkan untuk pembangkit listrik di 24 negara termasuk Indonesia.

Sumber panasbumi banyak terdapat di Indonesia, salah satunya yang terdapat di Sulawesi Tengah yaitu Daerah Panasbumi Pulu Kabupaten Sigi. Berdasarkan beberapa penelitian sebelumnya yang salah satunya telah dilakukan oleh Bakrun dkk, (2003), bahwa Daerah Panasbumi Pulu mempunyai sumber panasbumi yang dapat dikembangkan sebagai energi alternatif di masa mendatang.

Estimasi aliran panasbumi sangat penting dilakukan untuk mengetahui potensi panasbumi di Daerah Pulu tersebut. Panasbumi merupakan salah satu sumber daya alam yang memiliki potensi sangat besar untuk dapat dimanfaatkan. Kebutuhan manusia akan energi tiap tahun semakin meningkat sedangkan cadangan sumber energi semakin berkurang. Hal in membuat manusia berusaha untuk mencari sumber alternatif baru yang dapat dimanfaatkan untuk memenuhi kebutuhannya.

Salah satu teknik yang dapat digunakan untuk mengestimasi aliran panasbumi adalah dengan menggunakan data-data geomagnetik. Metode yang dapat memetakan anomali akibat panasbumi adalah metode geomagnet. Dalam penelitiaan panasbumi, metode geomagnet digunakan untuk mengetahui variasi medan magnet di Daerah penelitian. Dari metode geomagnet diperoleh nilai kedalaman atas, kedalaman basal, dan kedalaman bawah.

Penelitian estimasi kedalaman titik Curie di Daerah Panasbumi Pulu sebelumnya telah dilakukan oleh Janat (2014). Namun pada penelitian tersebut belum sampai pada penelitian aliran panas. Oleh sebab itu, dalam penelitian ini digunakan data kedalaman yang telah didapatkan dengan melanjutkan menghitung aliran panasbumi di Daerah Panasbumi Pulu untuk mengetahui arah aliran panasbumi tersebut.

Panasbumi adalah panas dari dalam bumi yang terdesak ke permukaan bumi dikarenakan oleh pergerakan bumi. Air hujan yang menyerap ke dalam bumi melalui celah-celah bumi ini membentuk cekungan air dan terkontaminasi panas yang kemudian naik ke permukaan dan dikeluarkan sebagai geyser, fumarol dan mata air panas (Moediyono, 2010).

Sistem panasbumi yang terdapat di daerah penyelidikan diduga akibat adanya bermacam-macam batuan seperti batuan Sekis hijau, batuan Granit geneis, batuan Sabak-Filit, batuan granit, Coluvium, dan Aluvium serta Sesar Palu Koro yang merupakan sesar terbesar di Sulawesi Tengah. Pada umumnya mata air panas di Daerah Pulu termasuk ke dalam tipe air panas bikarbonat yang sebagian berupa "immature waters "seperti di 
Desa Sibalaya, Walatana, Limba dan Simoro. Sedangkan Pulu, Mapane dan Kabuliburo berada di daerah "partial equilibrium" (Bakrun dkk, 2003). Temperatur air panas di Daerah Panasbumi Pulu sekitar $40^{\circ} \mathrm{C}-95^{\circ} \mathrm{C}$ dengan $\mathrm{pH} \quad 6,5 \quad-8,6$. Secara fisik air terlihat jernih dan tercium aroma belerang yang kuat (Bakrun dkk, 2003).

Analisis spektrum adalah salah satu analisis harmonik yang digunakan untuk menganalisis fenomena osilator harmonik di alam. Tujuan dari analisis ini adalah untuk mendapat distribusi spektrum dari fenomena osilator harmonik dan untuk menunjukkan karakteristik statiknya (Blakely, 1995). Dalam metode ini digunanakan hubungan metode magnetik dengan analisis spektrum untuk menyelidiki kedalaman panasbumi. Metode ini memberikan hubungan antara spektrum anomali magnetik dan kedalaman sumber magnet dalam domain frekuensi (Amiludin, 2008).

Dalam penelitian ini, sesuai dengan metode yang disajikan oleh Tanaka dkk (1999) untuk menghitung CPD, Blakely (1995) memperkenalkan power spektrum:

$$
\ln A=\ln B-|k| Z_{t}
$$

dimana $A$ adalah nilai amplitudo, $B$ adalah konstan, $k$ adalah kecepatan radial, dan $\mathrm{Z}_{\mathrm{t}}$ adalah kedalaman atas.

Okubo dkk dalam Aboud (2011) mengusulkan sebuah algoritma untuk memperkirakan kedalaman basal dari data magnetik dengan mempertimbangkan teknik pemodelan 2D untuk penentuan kedalaman ke dasar untuk blok tunggal. Kemudian, algoritma memperkirakan kedalaman centroid $\left(\mathrm{Z}_{0}\right)$ dari skala kemiringan radial rata-rata power spektrum di bagian bilangan gelombang tinggi, dan kedalaman ke atas $\left(\mathrm{Z}_{\mathrm{t}}\right)$ dari kemiringan radial rata-rata power spektrum anomali magnetik dibagian bilangan gelombang rendah, seperti yang terlihat pada Gambar 1. Spektrum densitas daya dihitung untuk setiap lintasan. Keuntungan dari power spectrum 2D adalah kedalaman sumber yang mudah ditentukan dengan mengukur kemiringan grafik energi spektrum. Sebuah contoh dari kekuatan spektrum sub regional ditunjukkan pada Gambar 1, setelah kedalaman atas diperkirakan, sebelumnya teknik ini diterapkan pada frekuensi daya skala radial rata-rata untuk memperkirakan kedalaman centroid $\left(\mathrm{Z}_{0}\right)$. Akibatnya kedalaman basal $\left(\mathrm{Z}_{\mathrm{b}}\right)$ kemudian diperoleh dengan menggunakan Persamaan (2). 


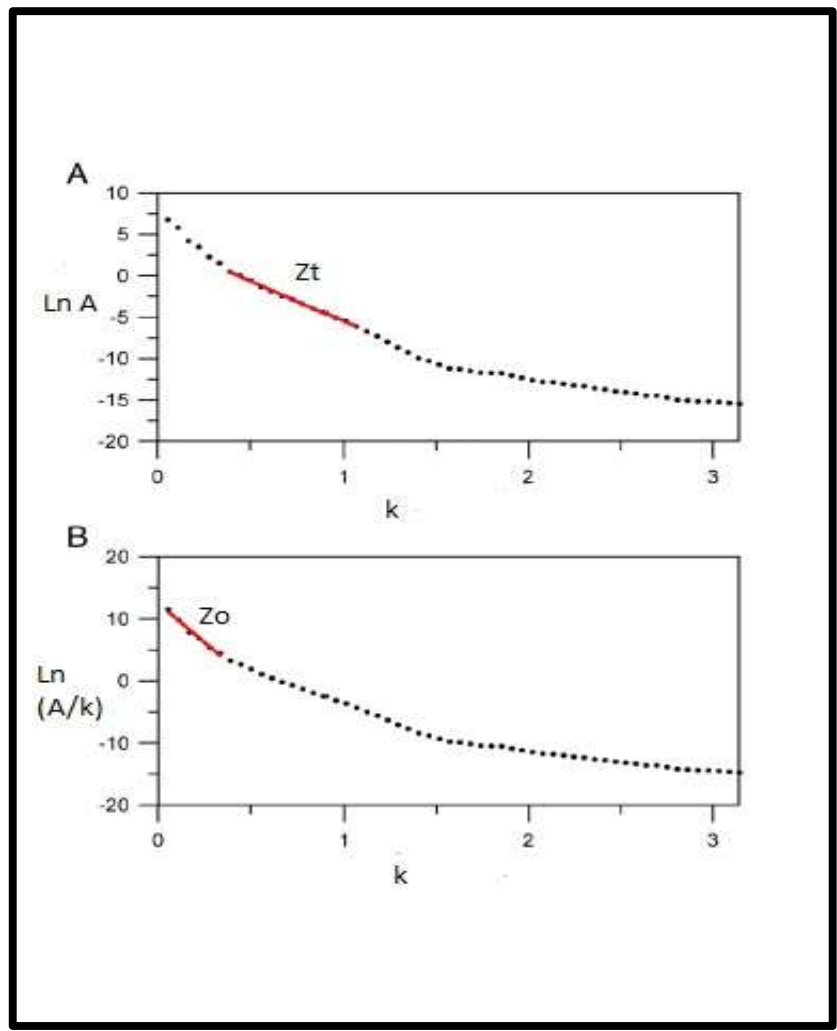

Gambar 1. Nilai $Z_{t}$ dan $Z_{0}$ dalam kemiringan Power spektrum (Aboud,dkk 2011).

Penelitian ini mengikuti prosedur Okubo dkk (1985) dan memperkirakan kedalaman untuk sumber magnet atas dan pusat massa $\left(\mathrm{Z}_{\mathrm{t}}\right.$ dan $\left.\mathrm{Z}_{0}\right)$. Dari power spektrum anomali total, kemudian $\mathrm{Z}_{0}$ dapat diestimasi dengan Persamaan (2) :

$\operatorname{Ln}\left\{\frac{(A)}{(k)}\right\}=\ln \mathrm{D}-|k| \mathrm{Z}_{0}$

Dengan memasang garis lurus melalui bilangan gelombang tinggi dan rendah bagian dari power spektrum radial rata-rata dari ln $\mathrm{A}$ dan $\mathrm{k}$, ln (A/k) dan $\mathrm{k}$, nilai $\mathrm{Z}_{\mathrm{t}}, \mathrm{Z}_{0}$ dapat diestimasi. Sinyal gelombang yang tertangkap pertama pada saat pengukuran merupakan sinyal gelombang untuk batas kedalaman sumber panasbumi $\left(\mathrm{Z}_{0}\right)$, dan selanjutnya merupakan sinyal gelombang untuk kedalaman atas. Oleh sebab itu plot grafik $\mathrm{Z}_{0}$ dilakukan pada nilai bilangan gelombang awal dan $\mathrm{Z}_{\mathrm{t}}$ pada bilangan gelombang di bawahnya. Selanjutnya nilai $\mathrm{Z}_{\mathrm{b}}$ dapat diestimasi dengan Persamaan (2) (Aboud, dkk 2011).

$\mathrm{Z}_{\mathrm{b}}=2 \mathrm{Z}_{0}-\mathrm{Z}_{\mathrm{t}}$

Gradien temperatur perhitungannya dinyatakan oleh Hukum Fourier dengan rumus :

$\frac{d T}{d Z}=\mathrm{Zb}$

Dalam persamaan ini, diasumsikan bahwa arah variasi suhu vertikal dan gradien temperatur $\frac{d T}{d Z}$ adalah konstan (Tanaka, 1999).

Temperatur Curie $(\theta)$ diperoleh dari titik kedalaman Curie (Zb) dan gradien temperatur $\frac{d T}{d Z}$ menggunakan persamaan berikut :

$\theta=\frac{d T}{d Z} Z b$

Aliran panas dan nilai gradien termal dihitung pada area pembahasan, hitungan diekspresikan oleh hukumnya fourier dengan rumus berikut.

$q=\lambda \frac{\mathrm{dT}}{d Z}$

dimana $\mathrm{q}$ adalah aliran panas dan $\lambda$ adalah koefisien dengan daya konduksi termal. Pada persamaan ini diasumsikan arah dari temperatur gradien $\frac{d T}{d z}$ adalah tetap. Sesuai 
dengan Tanaka,et al, (1999), suhu Curie ( $\theta)$ diperoleh dari kedalaman titik Curie $\left(\mathrm{Z}_{\mathrm{b}}\right)$ dan gradien hidrolik kritis termal $\frac{\mathrm{dT}}{d Z}$ menggunakan Persamaan berikut.

$\theta=\left[\frac{d T}{d Z}\right] Z_{b}$

Sumber panas antara permukaan bumi dan kedalaman titik curie, suhu permukaan adalah $0^{\circ} \mathrm{C}$ dan suhu curie sekitar $580^{\circ} \mathrm{C}$ adalah konstan (Nwankwo et al. 2011). Selain itu dari Persamaan (6) dan Persamaan (7) ditentukan hubungan antara kedalaman titik curie $(\mathrm{Zb})$ dan aliran panas (q) sebagai berikut:

$\mathrm{q}=\lambda\left[\frac{\theta}{\mathrm{zb}}\right]$

Dalam Persamaan ini, kedalaman titik Curie sebanding terbalik dengan aliran panas (Tanaka et al. 1999). Dalam penelitian ini suhu titik Curie $580^{\circ} \mathrm{C}$ dan konduktivitas termal $2,5 \quad \mathrm{Wm}-1^{0} \mathrm{C}-1$. Sebagai rata-rata untuk batuan beku digunakan sebagai standar (Nwankwo et al. 2011) di daerah penelitian. Untuk menghitung gradient dan daerah aliran panas termal digunakan Persamaan (8).

\section{METODE PENELITIAN}

Lokasi penelitian daerah panasbumi terletak di Desa Pulu, Kecamatan Dolo Selatan, Kabupaten Sigi, Provinsi Sulawesi Tengah. Untuk melihat secara jelas kondisi lokasi penelitian, di tampilkan peta titik lokasi penelitian pada Gambar 2.

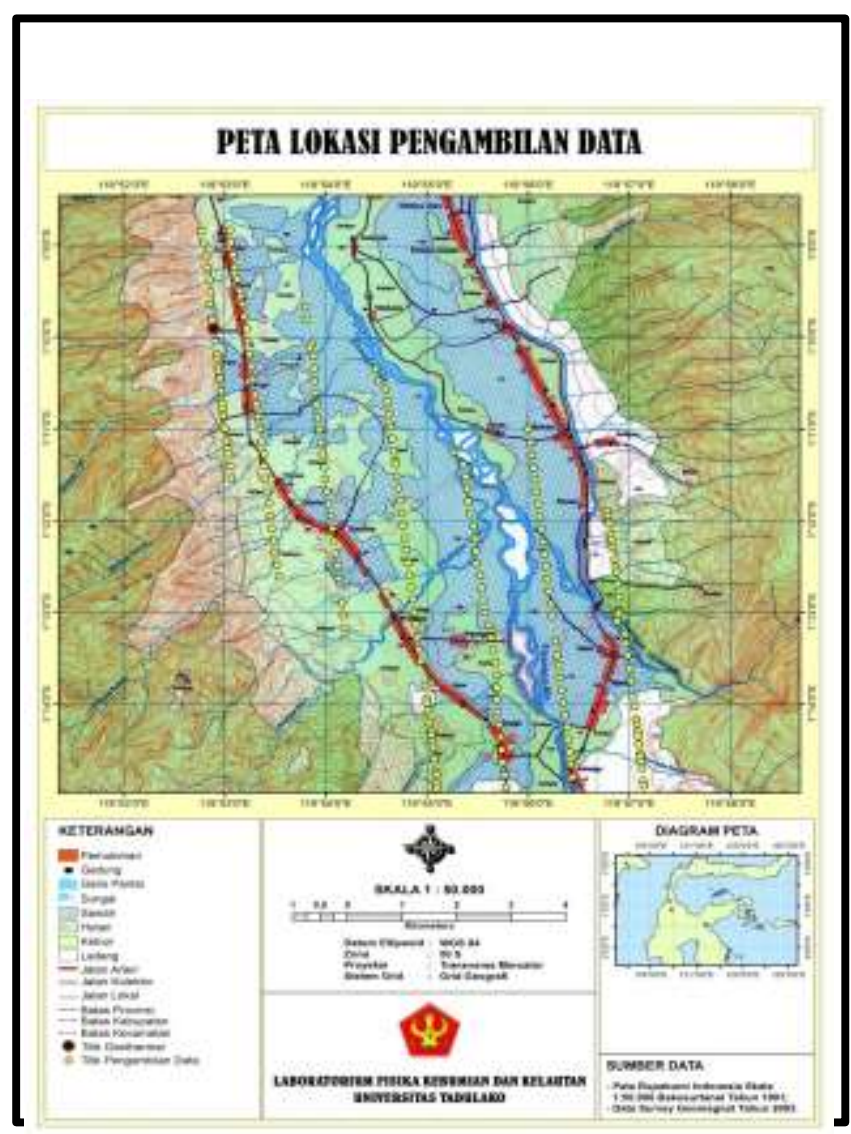

Gambar 2. Peta Lokasi Penelitian

Data yang digunakan dalam penelitian ini adalah data sekunder dari hasil penelitian yang dilakukan oleh Janat (2014). Data tersebut berupa pengolahan data mobile.

Proses untuk mendapatkan anomali panasbumi pada penelitian ini yaitu dengan membuat lintasan pada peta kontur anomali. Untuk mendapatkan kedalaman sumber panasbumi yaitu kedalaman atas, kedalaman tengah, dan kedalaman basal diperoleh dari hasil pengolahan software

\section{$\overline{\text { Estimasi Aliran Panasbumi Menggunakan Data Geomagnetik Di Daerah Panasbumi }}$ Pulu} (Fathana Rasyid dkk) 
Numeri yaitu berupa nilai frekuensi, dan bilangan real-imaginer. Nilai realimaginer tersebut diakarkuadratkan untuk mendapatkan nilai amplitudo (A). Setelah nilai amplitudonya diketahui kemudian dibuat grafik antara Ln A dan Ln A/k untuk masing-masing lintasan. Kemudian setiap lintasan dihitung nilai kedalaman dari sumber magnetik dengan menggunakan analisis spectrum. Berdasarkan kedalaman dan titik Curie maka akan diperoleh variasi gradien temperatur dan aliran panas, selanjutnya melakukan interpretasi pada setiap lintasan untuk mengetahui gradien temperatur dan aliran panasbumi pada daerah tersebut.

\section{HASIL DAN PEMBAHASAN}

Berdasarkan penelitian sebelumnya yang telah dilakukan oleh Janat, (2014), diperoleh nilai kedalaman basal $\left(Z_{b}\right)$ untuk setiap lintasan A- lintasan F berturut-turut $\mathrm{Z}_{\mathrm{b}}$ adalah 4,0899 $\mathrm{m} ; 2,5213 \mathrm{~m} ; 3,355 \mathrm{~m}$; 3,0451 m ; 4,044 m dan 1,4692 m.

Pada penelitian ini, menambahkan lintasan baru pada peta anomali medan magnet total yang akan digunakan pada estimasi kedalaman sumber magnetik di bawah permukaan, seperti yang terlihat pada Gambar 3.

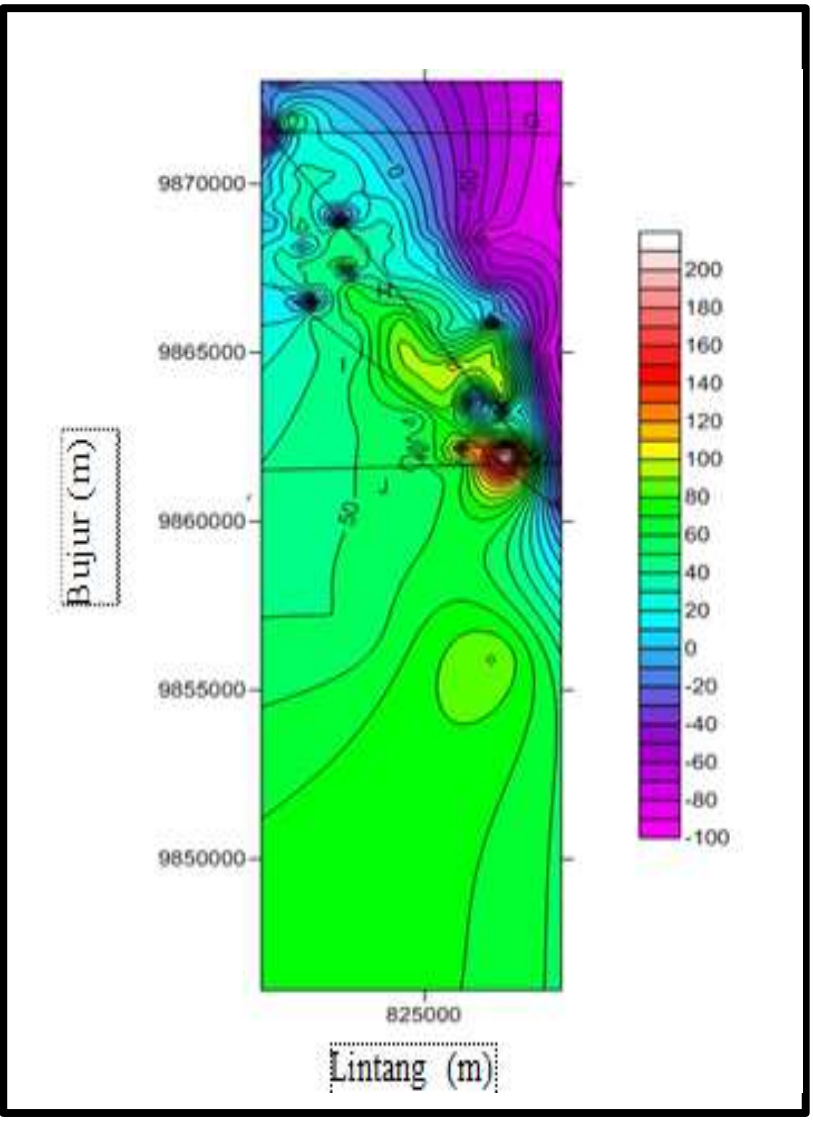

Gambar 3. Penampang Lintasan

Estimasi aliran panasbumsi bawah permukaan dengan menghitung nilai kedalaman basal $\left(\mathrm{Z}_{\mathrm{b}}\right)$ dari masing-masing lintasan baru yang telah ditambahkan serta nilai $Z_{b}$ yang diperoleh dari penelitian sebelumnya yang dilakukan oleh Janat (2014).

Terlihat pada Gambar 4. menunjukkan grafik estimasi aliran panas dan gradien termal pada lintasan $\mathrm{G}$, nilai kedalaman atas $\left(\mathrm{Z}_{\mathrm{t}}\right)$ yaitu 5.0039, kedalaman tengah $\left(\mathrm{Z}_{0}\right)$ yaitu $10,371 \mathrm{~m}$ dan kedalaman basal $\left(\mathrm{Z}_{\mathrm{b}}\right)$ atau biasa juga disebut Curie Point Depth (CPD) yaitu $11,7476 \mathrm{~m}$. 

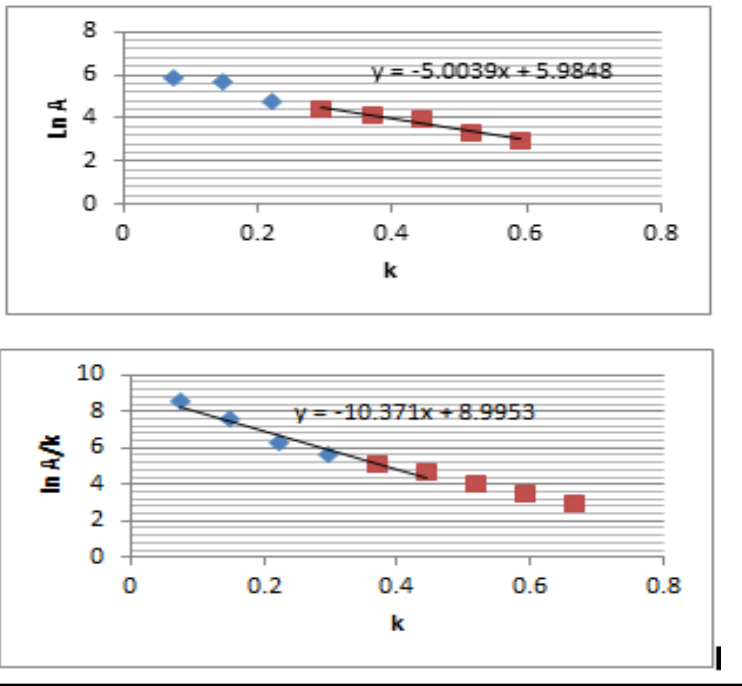

Gambar 4. Grafik kedalaman aliran panas dan gradien termal pada Lintasan $\mathrm{G}, \mathrm{Zt}$ (Ln A) dan ( $\mathrm{Z}_{0}$ Ln A/k).

Gambar 5. menunjukkan estimasi aliran panas dan gradien pada lintasan $\mathrm{H}$ dengan nilai $\left(\mathrm{Z}_{\mathrm{t}}\right)$ yaitu $3,8674 \mathrm{~m}$ dan nilai $\left(\mathrm{Z}_{0}\right)$ yaitu $6,1984 \mathrm{~m}$ dan nilai $\left(\mathrm{Z}_{\mathrm{b}}\right)$ yaitu $9,4716 \mathrm{~m}$.

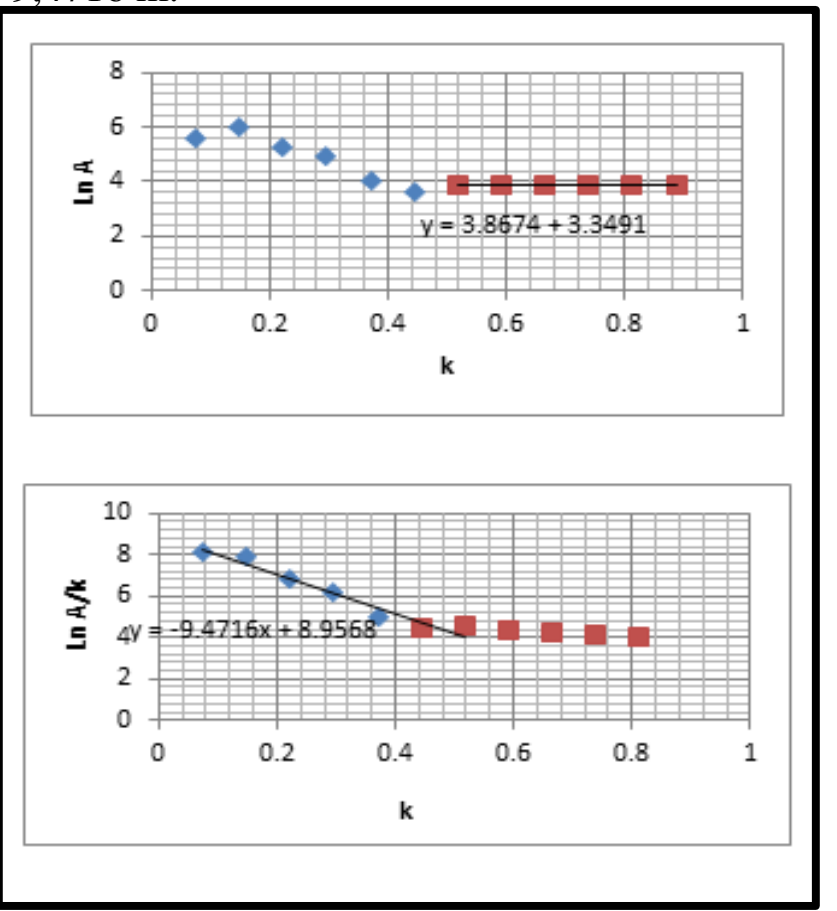

Gambar 5. Grafik kedalaman aliran panas dan gradien termal pada
Lintasan H, Zt (Ln A)dan Z $($ Ln $\mathrm{A} / \mathrm{k})$.

Gambar 6. menunjukkan grafik estimasi aliran panas dan gradien pada lintasan I dengan nilai $\left(Z_{t}\right)$ yaitu $3,2857 \mathrm{~m}$, $\left(\mathrm{Z}_{0}\right)$ dengan nilai $7,7482 \mathrm{~m}$ dan $\left(\mathrm{Z}_{\mathrm{b}}\right)$ dengan nilai 12,2639.

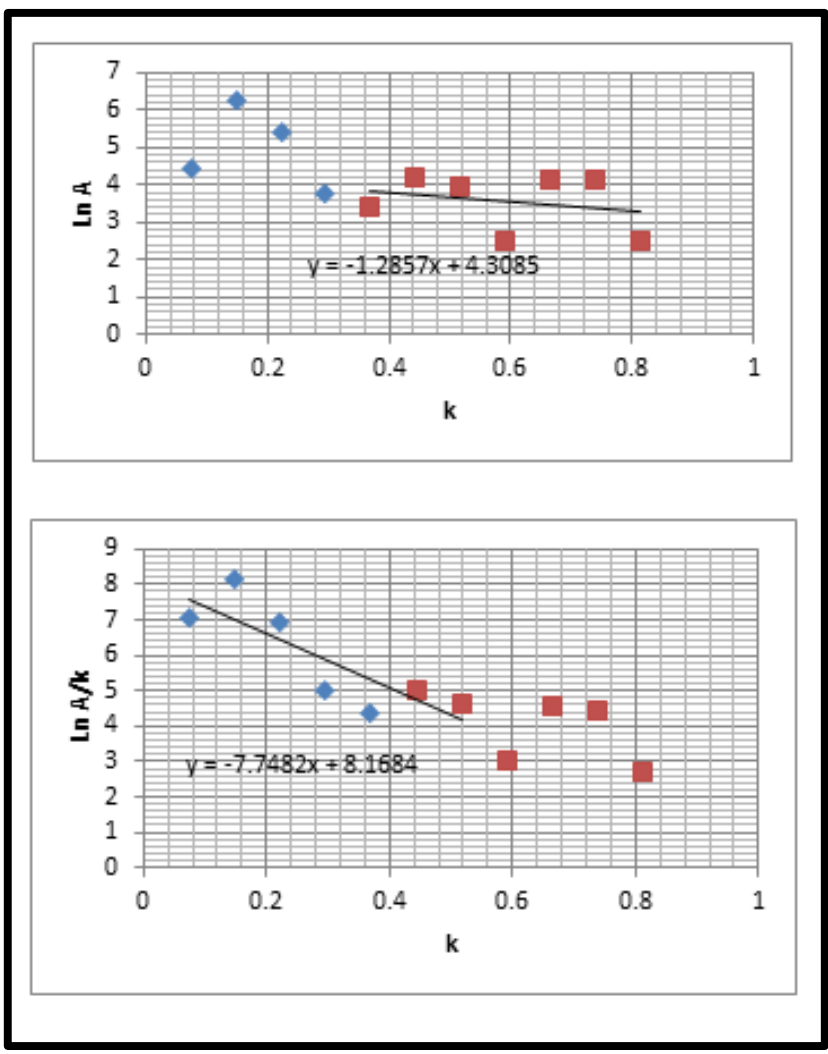

Gambar 6. Grafik kedalaman aliran panas dan gradien termal pada Lintasan I, Zt (Ln A) dan $\mathrm{Z}_{0}$ (Ln $\mathrm{A} / \mathrm{k})$.

Gambar 7. grafik estimasi aliran panas dan gradien pada lintasan $\mathrm{J}$ dan nilai $\left(\mathrm{Z}_{\mathrm{t}}\right)$ yaitu $3,912 \mathrm{~m}$, nilai $\left(\mathrm{Z}_{0}\right)$ yaitu 8,6608 $\mathrm{m}$ serta nilai $\left(\mathrm{Z}_{\mathrm{b}}\right)$ yang diperoleh yaitu $13,406 \mathrm{~m}$.

\section{$\overline{\text { Estimasi Aliran Panasbumi Menggunakan Data Geomagnetik Di Daerah Panasbumi }}$ Pulu}

(Fathana Rasyid dkk) 


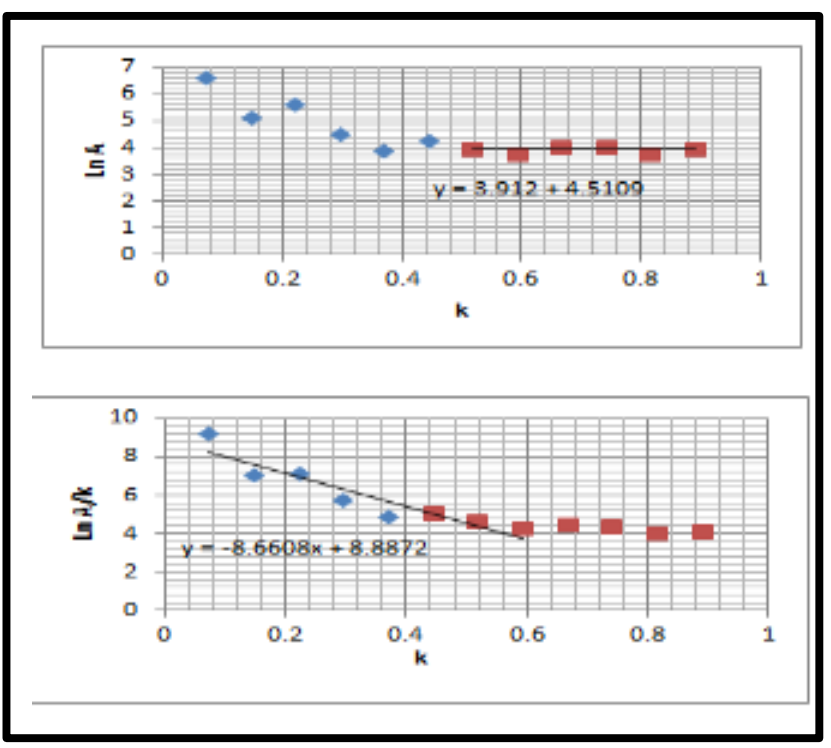

Gambar 7. Grafik kedalaman aliran panas dan gradien termal pada lintasan J, Zt (Ln A) dan $Z_{0}(\operatorname{Ln~A/k).~}$

Setelah mengestimasi masingmasing kedalaman basal $\left(\mathrm{Z}_{\mathrm{b}}\right)$ dan menghitung nilai gradien $\left(\frac{d T}{d Z}\right)$ serta nilai aliran panas (q). Nilai kedalaman yang diperoleh tersebut dapat dilihat pada Tabel 4.1.

Tabel 4.1. Nilai $Z_{b}, \frac{d T}{d Z}$ dan q untuk masing-masing lintasan

\begin{tabular}{|c|c|c|c|c|c|}
\hline No & $\mathrm{Z}_{\mathrm{g}}(\mathrm{II})$ & $\mathrm{Z}(\mathrm{I})$ & $Z_{s}(\mathrm{II})$ & $\operatorname{didg}\left({ }^{\circ} \mathrm{Cm}\right)$ & $q\left(\mathbb{m} \mathbb{W} \mathbb{m}^{2}\right)$ \\
\hline A & $6,425^{*}$ & $2115^{*}$ & $40096^{*}$ & 0,014182 & 0,035456 \\
\hline B & $7,267^{\circ}$ & $1,207^{*}$ & $2,5213^{*}$ & 0,023004 & 0,05751 \\
\hline C & $1,130^{\circ}$ & $1,732^{*}$ & $3355 *$ & 0,172876 & 0,432191 \\
\hline$D$ & $1,22 *^{*}$ & $1584^{*}$ & $3,0451^{*}$ & 0,019047 & 0,047617 \\
\hline$E$ & $1,839^{\circ}$ & $2114^{*}$ & $4,044^{\circ}$ & 0,143422 & 0,358556 \\
\hline F & $2054^{*}$ & $1,528^{\circ}$ & $1,4692^{*}$ & 0.39477 & 0,98693 \\
\hline G & 10371 & 5,0039 & 11,7476 & Q,4937 & 0,12343 \\
\hline $\mathrm{H}$ & 6,1985 & 3,8674 & 9,4716 & 0,3847 & 0,96182 \\
\hline 1 & 7,7482 & 3,2857 & 122639 & $0,0,473$ & 0,11820 \\
\hline I & 8,6608 & 3912 & 13,426 & 0,43253 & 0,10813 \\
\hline \multicolumn{3}{|c|}{ Ratarata } & 6,5413 & 0,21255 & 0,32298 \\
\hline
\end{tabular}

Tabel 4.1 terlihat bahwa hasil perhitungan yang dilakukan, lintasan $\mathrm{J}$ mempunyai nilai kedalaman basal yang paling besar dibandingkan dengan lintasan lainnya, dan nilai aliran panas pada lintasan J lebih kecil, sedangkan lintasan $\mathrm{H}$ mempunyai nilai kedalaman basal yang paling kecil dibandingkan dengan nilai kedalaman basal lintasan lainnya, dan nilai aliran panasnya lebih besar dibandingkan dengan aliran panas lintasan lainnya. Hal ini sesuai dengan literatur yang menyatakan kedalaman titik curie berbanding terbalik dengan aliran panas (Tanaka et al.,1999).

Sumber panas antara permukaan bumi dan kedalaman titik Curie, suhu permukaan adalah $0^{\circ} \mathrm{C}$ dan suhu titik Curie adalah $580^{\circ} \mathrm{C}$ serta konduktivitas termal $2,5 \mathrm{Wm}^{-10} \mathrm{C}^{-1}$ rata-rata untuk batuan beku digunakan sebagai standar di daerah penelitian (Nwanko et al., 2011).

Berdasarkan nilai yang terlihat pada Tabel 4.1 dapat diketahui bahwa nilai ratarata gradien temperatur pada setiap penambahan $1 \mathrm{~m}$ yaitu $0,21255{ }^{0} \mathrm{C} / \mathrm{m}$, Nilai ini sangat jauh dibanding dengan proses terbentuknya energi panasbumi yang dipicu oleh aktivitas vulkanik di dalam perut bumi. Sedangkan Nilai Aliran panas pada lintasan $\mathrm{J}$ lebih kecil dari semua lintasan yaitu $0,10813 \mathrm{mWm}^{-2}$ dan nilai aliran panas pada lintasan $\mathrm{H}$ lebih 
besar dari semua lintasan yaitu 0,96182 $\mathrm{mWm}^{-2}$ maka arah aliran panasnya mengalir dari lintasan $\mathrm{J}$ menuju ke lintasan $\mathrm{H}$ atau dari arah selatan menuju ke arah utara.

Aliran panas rata-rata untuk daerah panasbumi Pulu adalah 0,32298 $\mathrm{mWm}^{-2}$, panas ini sangat kecil jika dibandingkan dengan energi matahari yang ditangkap oleh bumi yang mencapai 1000 watt energi matahari, dan lebih terkonsentrasi di beberapa titik tertentu dimana panas dipindahkan melalui konveksi, seperti di punggung laut dan rekahan mantel.

Berdasarkan hasil penelitian tentang Estimasi Aliran Panas di Daerah Panasbumi Pulu, dapat disimpulkan bahwa nilai aliran Panasbumi mencapai 0,32298 $\mathrm{mWm}^{2}$. Dan arah aliran panasnya mengalir dari lintasan $\mathbf{J}$ menuju ke lintasan $\mathrm{H}$ atau dari arah selatan menuju kearah utara.

Untuk dapat lebih mengetahui estimasi aliran panas bawah permukaan, perlu dilakukan penelitian lebih detail menggunakan metode geofisika lainnya guna mendapatkan hasil yang terbaik.

\section{DAFTAR PUSTAKA}

Aboud E, Ahmed Salem, Mahmoud Mekkawi, 2011, Curie depth map for Sinai Peninsula, Egypt deduced from the analisis of magnetic data, Jurnal Tectonophysics Vol. 506, Jeddah

Amiludin, 2008, Analisis power spektrum Data Gaya Berat Untuk memperkirakan Kedalaman Bidang Batas Anomali Lokal-Regional, Prosiding Program Studi Geofisika, Universitas Lampung, Bandar Lampung

Bakrun, H. S., Bangbang Sulaeman, Ario Mustang, Solaviah, 2003, Penyelidikan Terpadu Panasbumi Pulu Kabupaten Donggala, Kolokium Hasil Kegiatan Inventarisasi Sumber Daya Mineral, Bandung.

Blakely. R. J., 1996, Potential theory in gravity and magnetic Applications, Cambridge University. New York

Janat, N. R , 2014, Identifikasi Sumber Panasbumi Menggunakan Metode Geomagnet Dengan Analisis Spektrum Di Lapangan Panasbumi Pulu, Skripsi jurusan Fisika FMIPA Universitas Tadulako, Palu.

Moediyono, 2010, Pembangunan Pembangkit Listrik Tenaga Panas Bumi (PLTPB), Universitas Diponegoro, Semarang

Nwankwo,L.I, Olasehinde , P.I and Akoshile,C.O.,2011, Heat flow anomalies from the spectral analysis of Airborne Magnetic data of Nupe Basin Nigeria. Asian Journal of Earth Sciences. Vol. 1, No. 1, PP 1-6

Tanaka, A., Okubo, Y., And Matsubayashi, O., (1999), CuriePoint Depth Based On Spectrum Analysis Of The Magnetic Anomaly Data In East And Southeast Asia, Tectonophysics Vol. 306, 461-470.

Telford, W M, L.P Geldart and R.E Sherriff, 1996, Applied Geophysic Second Edition, Cambridge University Press, Australia 